\title{
Public Infrastructure and Economic Takeoff
}

\author{
Prakash Chandra Sapkota \\ Graduate School of Economics, Osaka City University \\ 3-138 Sugimoto, Sumiyoshi-ku, Osaka 558-8585, Japan \\ Tel: 81-6-6605-2251 E-mail: prakashchandrasapkota@gmail.com
}

Received: February 10, 2020 Accepted: March 5, 2020 Published: March 8, 2020

doi:10.5296/ber.v10i1.16628

URL: https://doi.org/10.5296/ber.v10i1.16628

\begin{abstract}
The purpose of this paper is to incorporate the role of public infrastructure investment on economic takeoff process in underdeveloped and emerging economies in a dynamic general equilibrium model. We use a two-period overlapping generations model, and consider two types of technologies (traditional and modern) that are used to produce the final output of firms. This paper confirms that economic takeoff is possible only when the capital per labor unit exceeds a certain threshold level. Thus, the takeoff process depends on the productivity race between traditional and modern technologies with increasing public infrastructure investment, while public infrastructures foster the productivity of both technologies. Similarly, an effective tax rate supports the takeoff process by stimulating the wage rate which in turn increases the capital per labor along with the saving rates. Hence, we clarify the conditions required for succeeding in the takeoff of an economy. In addition, we review some empirical evidence related to the output elasticity of public infrastructures.
\end{abstract}

Keywords: Public infrastructure, Early-stage, Economic takeoff, Threshold, Effective tax rate

\section{Introduction}

It is widely recognized that infrastructure is a crucial ingredient of economic growth and development. The lack of infrastructure investment hinders the economic takeoff process in underdeveloped and emerging economies. At the early stage of development, government financing is the only source for investing in public assets such as, infrastructure capital (public capital). In recent years, the role of infrastructure investment has received amplified attention. The latest reports show globally 840 million people live at a distance of more than 2 kilometers from all-weather roads, 2.3 billion people live with the lack of sanitation, about 1 billion people are out of electricity and 2.6 billion in developing and underdeveloped economies don't have constant access to the electricity. Similarly, more than 4 billion people 
live without the internet where 90 percent of them are from developing and underdeveloped economies. The main factor behind this misfortune is the lack of sufficient investment in the infrastructure sector. A study by Oxford Economics (2017) suggests that between 2016 and 2040 , the global infrastructure sector needs an annual investment of US\$3.7 trillion rather than a currently forecasted trend of US $\$ 3.2$ trillion per year, which was, in average, US $\$ 2.0$ trillion per year between 2007 and 2015. The study also states that the largest investment requirements are in the road infrastructure and electricity sector respectively.

Table 1. Indicators of regional infrastructure development and economic performances

\begin{tabular}{|l|l|l|l|l|l|l|l|}
\hline Indicators & $\mathbf{1 9 9 0}$ & $\mathbf{1 9 9 5}$ & $\mathbf{2 0 0 0}$ & $\mathbf{2 0 0 5}$ & $\mathbf{2 0 1 0}$ & $\mathbf{2 0 1 5}$ \\
\hline SOUTH ASIA & 583.48 & 667.19 & 794.35 & 985.45 & 1255.85 & 1591.96 \\
\hline GNI per capita (constant 2010 US\$) & 2.24 & 2.09 & 1.90 & 1.68 & 1.43 & 1.26 \\
\hline Population growth (annual \%) & 47.30 & & 38.00 & 33.74 & 24.58 & 12.40 \\
\hline Poverty headcount ratio & 0.56 & 1.18 & 2.67 & 3.90 & 2.86 & 1.96 \\
\hline Fixed telephone subscriptions & & 48.02 & 57.36 & 64.39 & 73.09 & 84.49 \\
\hline Access to electricity (\% of pop.) & & 0.02 & 0.47 & 2.53 & 7.21 & 23.20 \\
\hline Internet users (per 100 people) & & 16680.61 & 18977.37 & 20488.88 & 21967.73 & 22352.48 \\
\hline Total rail lines (users density per km) & & 23.99 & 24.93 & 30.49 & 30.58 & 27.22 \\
\hline Gross fixed capital formation/GDP & 24.47 & & & & \\
\hline EAST ASIA \& PACIFIC & & 4789.63 & 5382.82 & 6328.14 & 7705.63 & 9291.81 \\
\hline GNI per capita (constant 2010 US\$) & & 1.20 & 0.94 & 0.74 & 0.68 & 0.68 \\
\hline Population growth (annual \%) & 1.51 & 61.32 & & & 18.92 & 11.21 & 2.31 \\
\hline Poverty headcount ratio & 5.35 & 8.08 & 13.89 & 23.97 & 22.29 & 16.84 \\
\hline Fixed telephone subscriptions & 94.05 & 90.96 & 93.10 & 93.82 & 95.56 & 97.11 \\
\hline Access to electricity (\% of pop.) & 0.01 & 0.21 & 5.62 & 14.72 & 34.27 & 49.84 \\
\hline Internet users (per 100 people) & & 18745.54 & 18232.04 & 20912.19 & 19298.49 & 22442.11 \\
\hline Total rail lines (users density per km) & & 31.29 & 29.17 & 30.81 & 31.53 & 31.97 \\
\hline Gross fixed capital formation/GDP & 29.66 & & & & \\
\hline
\end{tabular}

Note: The poverty headcount ratio is represented at US\$1.90 a day (2011 PPP) (\% of the population). A fixed telephone line subscription is presented per 100 people. Regarding total rail lines (users density per km), the World Bank has only country-specific rail lines (total route-km) data, and we calculated the total rail lines route-km and divided by the total population in the region. Data Sources: World Bank.

According to World Bank (2018), as concluded in its report 'Poverty and Shared Prosperity', Sub-Saharan Africa is the poorest region in the world where more than $50 \%$ of the world's extremely poor people live. Similarly, South Asia is the second poorest region where more than $33 \%$ of the world's poor people live. According to table 1, in South Asia, $12.10 \%$ of people still live with US\$1.90 per day which was 47.30 in 1990, whereas in East Asia and Pacific, $2.3 \%$ of people live with US\$1.90 per day which was $61.30 \%$ in 1990 . In regard to reducing poverty, East Asia and the Pacific region have made outstanding progress. Comparing these two economies, the population growth rate in East Asia and the Pacific region is decreasing sufficiently with large GNI per capita, whereas South Asia is placed far behind in this regard. Similarly, South Asia remains behind in infrastructure development in 
comparison to East Asia and Pacific Region. In this respect, South Asia has weaker penetration in access to electricity, internet and telephone, but in railway infrastructure, both regions have not made significant progress. East Asia and the Pacific region have a sufficiently larger amount of gross fixed capital formation even though there is not a large difference in the ratio of capital formation to GDP in comparison to South Asia because East Asia and the Pacific region have larger GNI per capita. Thus, with the gradual growth in infrastructure development both regions are moving onward to escape from poverty and gain momentum toward sustainable development. The difference is that East Asia and the Pacific region is near to get the position of the middle-income region, while South Asia is not. Accordingly, these situations significantly validate the role of infrastructure investment for expelling countries out of poverty and leading into a new era of development.

Economists have given their widespread attention to the ongoing debates on infrastructure, economic development and poverty alleviation around the world. Among them, some economists have considered the issue of early-stage takeoff and development while others have concentrated on aggregate output growth, income distribution, inequality, welfare, and other dimensions. Starting from the seminal contribution of Rosenstein-Rodan (1943), the Big Push theory was developed for mobilizing large investment in the economy in the early stage of evolution. ${ }^{1}$ A broader concept of takeoff in the literature was put forwarded by Rostow (1959) where he classifies 5 stages of growth in the economy. ${ }^{2}$ Rostow determines sufficient social overhead capital, modernizing the agriculture sector and trade as the preconditions for takeoff. Similarly, industrialization, modernization and infrastructure development have been historically taken as the attributes of the take-off stage. ${ }^{3}$ These studies elaborated only the basic features of takeoff but the role of public capital in the process has not been shown precisely. Thus, Aero and Kurz (1970) and later Barro (1990) are the first who stressfully advocate the role of public capital in growth literature. By defining public capital as a complementary input to private production, they establish a positive and significant effect of public capital on long-run growth. After these pioneering contributions, majorities of literature in this area are influenced by Barro's endogenous framework identifying the vital role of public capital, specifically, the physical infrastructure capital [see Bucci and Del Bo. (2011), Hashimzade and Myles (2010) and more].

In recent literatures, studies of public capital have been diversified into education, public health, income distribution, welfare and many other dimensions of economics. ${ }^{4}$ By defining infrastructure as an engine of growth, Agenor (2006) and Agenor and Neaidis (2011) suggest that public infrastructure is essential to improve health and education in the endogenous

\footnotetext{
${ }^{1}$ By supporting Big Push theory, Easterly (2006) suggests mobilizing foreign aid for an increase in domestic investment which is essential for escaping from poverty and rapid acceleration of growth.

${ }^{2}$ Rostow (1959) defines 5 stages of growth such as 'The Traditional Society', 'Pre-condition for Take-off', 'The Take-off', 'The Drive to Maturity' and 'The Age of High Mass Consumption'.

3 Later, Sachs (2005) in his book 'The End of Poverty Trap' advocates six forms of capital investment is needed for poverty alleviation and takeoff success in the economy, they are human capital, business capital, infrastructure capital, natural capital, public institutional capital and knowledge capital. He argues these capitals should be improved sufficiently to lift up from the poverty trap.

4 See Glomm \& Ravikumar (1997), Getachew (2010), Agenor (2006, 2008), Agenor and Neaidis (2011), Bucci and Del Bo. (2011), Chen (2006), Ott and Tursosky (2006), Nakamura and Mihara (2016), Hashimazde and Myles (2010), Cazzavillan (1996) and more.
} 
framework. ${ }^{5}$ In addition, in a study based on the two-sector model, Getachew (2010) discovers a disproportionate impact of public capital on the economy. For example, some infrastructure stock and flow have a larger impact on certain groups of people, whereas at the same time another group of people might have been less benefitted. From the early 1990s, most of the literatures in this area have focused on non-physical capital based on the dynamic equilibrium models. However, in early-stage economies, the rate of return to physical capital is larger than non-physical capital and the development process is fuelled by physical capital accumulation (Galor and Moav, 2004). Regardless of the different dimensions of the studies, most of the literatures seem to have adopted infrastructure capital as the main engine of the economy; however, an in-depth study from the perspective of the takeoff process in the poor economies has not been conducted in the theoretical ground. Thus, in line with Galor and Moav (2004), this paper primarily investigates the role of public infrastructure capital on the takeoff process. ${ }^{6}$

Taking this into account, this paper develops an overlapping-generations (OLG) model for evaluating the possibility of takeoff in underdeveloped and emerging economies. In addition, we consider two types of technologies that are used in production such as, traditional technology and modern technology, where traditional technology only uses labor input but modern technology uses both labor and capital input. Here, the existence of traditional technology indicates the early-stage economies where agriculture is the backbone of the economy. More convincingly, we can refer it to 'the traditional society' - the first stage of the economy as per the classification of Rostow (1959). In our model, we assume there are three stages of the development process. In the first stage, no government investment in infrastructure is assumed. When the government started investing in infrastructure capital, we call it a second stage or also can say the takeoff stage, where government investment fosters productivity of both technologies. To understand more easily, traditional technology indicates the traditional agriculture sector and modern technology indicates the manufacturing sector. If the economy achieves success in takeoff, it enters into the third stage of development, where increasing public capital raises income and reduces poverty in the economy.

In this paper, our hypothesis is that increasing government investment in infrastructure drives the economy from the traditional trap to takeoff and development. The possibility of takeoff depends on the productivity race between traditional technology and modern technology. Convincingly, if the productivity of the modern sector is relatively larger than that of the traditional sector with increasing public capital, the threshold level in the economy decreases and the economy gets success in the take-off process. In contrast, if the productivity of the traditional sector is larger than that of the modern sector with increasing public capital, the

\footnotetext{
5 In addition, Agenor (2008) explains the effects of infrastructure on the production of health service and welfare. Furthermore, Glomm and Ravikumar (1997) and Nakamura and Mihara (2016) have also contributed in this regard by using two periods and three-period OLG model respectively with dynamic equilibrium in the economy. A similar type of study by Chatterjee and Turnovsky (2012) model the differential impact of public infrastructure on wealth, income and welfare, and identify a crucial role of public spending. Their model shows increasing public capital raises average welfare but simultaneously increases welfare inequality, and hence they suggest imposing consumption tax.

6 We focus on public infrastructure capital (physical infrastructure) not private infrastructure because in low-income economy initially private sector can't be able to invest in infrastructure.
} 
take-off process is disrupted because of the increasing threshold value. Economist Rostow (1959) also documents that the economy should transition from traditional to the manufacturing sector for getting success in the takeoff process. If the economy succeeds in the takeoff process, an increase in the share of infrastructure eases the shift from low growth equilibrium to high growth steady-state, characterized by comparatively low savings and capital per labor unit.

In our model, the lump-sum tax, which finances government investment is the driving force of takeoff and has a crucial role. An effective tax rate supports the take-off process by stimulating the wage rate and thus capital per labor unit. We assume government collects lump-sum tax from the households and distributes resources in a distortionary fashion. By assumption, government can't finance deficits by issuing debt, and surplus by accruing assets, and it keeps its budget balanced at any period. The government has many ways to distribute revenue; however, we concentrate only on infrastructure investment, where infrastructures are roads, railways, water and sanitation facilities, electricity, telecommunications, etc. We consider benevolent government and the public goods are free of user fees, non-rivalry and non-excludable, and each firm in the economy can use it autonomously. Hence, this paper clarifies the role of public infrastructures on economic development.

The rest of the paper is organized as follows. Section 2 explains our model. In section 3, we examine threshold and takeoff with pubic infrastructure capital. Similarly, we also evaluate a rise in income and capital dynamics with increasing public capital. Section 4 briefly reviews the empirical literature, and section 5 contains concluding remarks.

\section{The Model}

Consider a closed overlapping-generations economy where Individuals live for two periods (young and old). In each period, the economy produces single homogenous goods that are used for consumption as well as investment. The firm in the economy has two types of production technologies, namely traditional and modern technology. The government invests in public capital which is infrastructure capital, and every firm has equal excess to the public capital without a user fee.

\subsection{Individuals}

A young individual supplies one unit of labor in-elastically in period $t$, for which it is compensated at real wage, but in period $t+1$ individual doesn't work. Individual decides how much income is to be consumed and how much is to be saved for next period consumption. We assume the population growth is constant in each period. Moreover, an individual pays lump-sum tax which is determined by the government. Thus, the lifetime utility maximization for an individual is,

$$
\max _{c_{t}, c_{t+1}} U \ln c_{t}+(1-\beta) \ln c_{t+1} .
$$

Individual's wage income is used for $t$ period's consumption, tax to the government and remaining saving for next period consumption, and hence, the budget constraint equations 
are,

$$
\begin{gathered}
w_{t}-\tau=c_{t}+s_{t}, \\
c_{t+1}=\left(1+r_{t+1}\right) s_{t},
\end{gathered}
$$

where $0<\beta<1, r_{t+1}>-1$. $s_{t}$ is saving rate, $c_{t}$ is consumption in ' $\mathrm{t}$ ' period, $r_{t+1}$ is the interest rate, $\tau$ is the exogenous lump-sum tax rate and $c_{t+1}$ is the consumption for the next period. The first-order conditions are as follows,

$$
\begin{gathered}
s_{t}=(1-\beta)\left(w_{t}-\tau\right), \\
c_{t}=\beta\left(w_{t}-\tau\right), \\
c_{t+1}=\left(1+r_{t+1}\right)(1-\beta)\left(w_{t}-\tau\right) .
\end{gathered}
$$

Saving is the non-disposed income of period 't', which appears a stock of financial capital at the end of period ' $\mathrm{t}$ ' and goes to the economy as a capital investment by firms. If the consumption in 't' period increases, saving decreases and vice versa.

\subsection{Firms}

We assume firms run under perfect competition. Two types of technology can be used by the firm: traditional and modern. Traditional technology only uses labor input but modern technology uses both labor and capital inputs. A firm decides which type of technology should be used to minimized costs. However, both technologies' firms can use public infrastructure capital as a complementary input. A production function for traditional technology is,

$$
Y_{t}=A_{\mathrm{T}} N_{\mathrm{T} t}
$$

where $A_{\mathrm{T}}>0 . \quad Y_{t}$ is the output, and $N_{\mathrm{T} t}$ is the labor input in traditional technology.

At the same time, we assume a Cobb-Douglas production function where the homogenous output of $\mathrm{Y}$ with the combination of $\mathrm{K}$ and $\mathrm{N}$ with a constant return to scale is produced by modern technology firms. The output produced at the time, $t$, is,

$$
Y_{t}=A_{\mathrm{M}} K_{t}^{\alpha} N_{\mathrm{M} t}^{1-\alpha}
$$

where $A_{\mathrm{M}}>0,0<\alpha<1$. $Y_{t}$ is output, $K_{t}$ is capital input, $N_{\mathrm{M} t}$ is the total amount of labor in modern technology.

We assume the following condition,

$$
A_{\mathrm{T}}=A_{\mathrm{T}}(G), A_{\mathrm{M}}=A_{\mathrm{M}}(G),
$$

where $A_{\mathrm{T}}(G)>0, A_{\mathrm{M}}(G)>0, A_{\mathrm{T}}^{\prime}(G)>0, A_{\mathrm{M}}^{\prime}(G)>0$. $G$ is the public infrastructure that firms can use without user fees. By using public capital both technologies can increase their productivity. If the firm decides to use traditional technology, the wage rate equals to shift parameter $A_{\mathrm{T}}$ :

$$
w_{t}=A_{\mathrm{T}}
$$


If the firm decides to use modern technology, the first-order conditions are,

$$
\begin{gathered}
r_{t}=\alpha A_{\mathrm{M}} k_{t}^{\alpha-1}, \\
w_{t}=(1-\alpha) A_{\mathrm{M}} k_{t}^{\alpha} .
\end{gathered}
$$

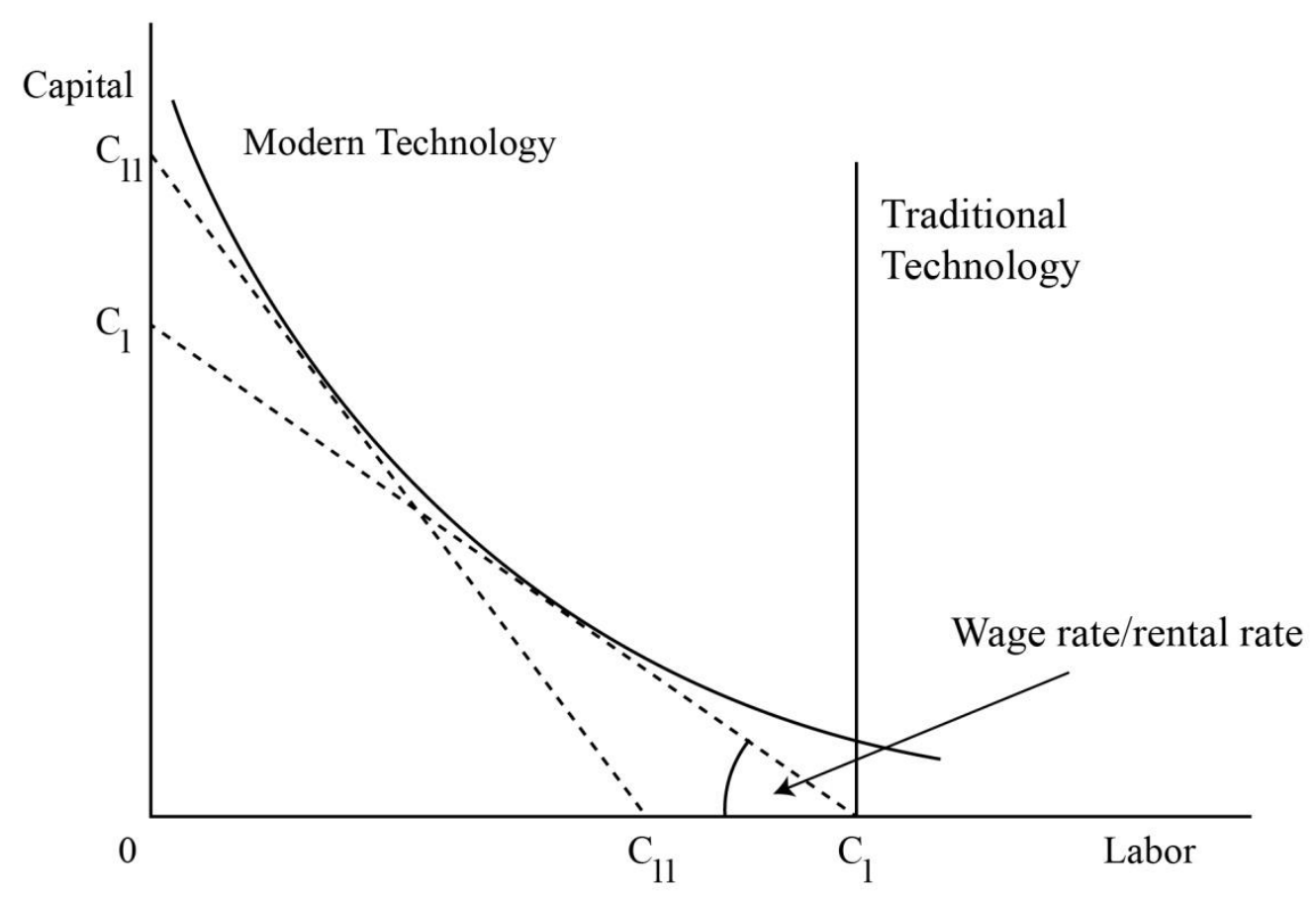

Figure 1. Isoquants and the ratio of factor prices

Figure 1 depicts the ratio of firms using traditional technology and modern technology. In $C_{I}$ cost line, both inputs are indifferent to the given output, thus both types of technologies are indifferently applied. However, $\mathrm{C}_{\mathrm{II}}$ represents, when the ratio of wage rate to rental rate increases, it means labor becomes relatively expensive than the rental rate, and as a result, the firm decides to reduce relatively expensive labor and shift to modern technology. Hence, technology adoption is determined by factor prices in our assumptions.

\subsection{Government}

For simplicity we assume, the government spends on infrastructure capital by levying lump-sum tax on an individual's wage income. It means, by assumption, the government can't finance by deficits by issuing debt, and surplus by accruing assets, and it keeps its budget balanced at any period. Thus, the government's budget constraint is,

$$
G=\tau N,
$$

where $G$ is total infrastructure capital (public capital) spending and $\tau$ is the lump-sum tax rate and $N$ is the total amount of labor. In addition, we assume public goods are free of the user fee, non-rivalry and non-excludable, and the benevolent government which works as a social planner. 


\section{Public Infrastructure and Takeoff of the Economy}

\subsection{Equilibrium Condition}

We assume the following equation,

$$
\mu_{t} K_{t}=K_{t}^{e}
$$

where $0<\mu_{t}<1$ is the ratio of technology used, $\mu_{t} K_{t}$ is the ratio of the firm using modern technology and $K_{t}{ }^{e}$ is the capital in the economy in equilibrium condition.

$$
\mu_{t} N_{\mathrm{M} t}+\left(1-\mu_{t}\right) N_{\mathrm{T} t}=N_{t},
$$

where $N_{t}$ is the total labor supply in the economy. From (14) and (15), capital per labor in market equilibrium condition is,

$$
k_{t}=\frac{\mu_{t} K_{t}^{e}}{\mu_{t} N_{\mathrm{M} t}+\left(1-\mu_{t}\right) N_{\mathrm{T} t}} .
$$

Re-writing (12) in the following form:

$$
(1-\alpha) A_{\mathrm{M}}\left(\frac{K_{t}}{N_{\mathrm{M} t}}\right)^{\alpha}=A_{\mathrm{T}}
$$

There are two possibilities in the equilibrium condition: either using both technologies or only using modern technology. When both technologies are used, the following threshold condition can be identified,

$$
k_{t} \leq \underline{k} \equiv\left[\frac{A_{\mathrm{T}}(G)}{(1-\alpha) A_{\mathrm{M}}(G)}\right]^{1 / \alpha}
$$

where $k_{t} \equiv K_{t} / N_{t}$ is the capital per labor unit in the period t, and $\underline{k}$ is the threshold point of capital per labor unit.

When $k_{t} \leq \underline{k}$, both technologies are appropriate. An increase in the productivity of traditional technology increases the threshold, whereas an increase in the productivity of modern technology decreases the threshold, and capital per labor possibly surpasses the threshold level. An increase in capital per labor unit increases the ratio of the firm using modern technology. The wage rate and interest rates are constant as long as (18) holds. By assuring the dynamic path in our model, savings made by each individual in period $t$ are used for capital accumulation. As $K_{t}$ constitutes the non-human wealth in the closed economy at the beginning of period $(t+1)$, we therefore have,

$$
S_{t}=s_{t} N_{t}=K_{t+1}
$$

where $s_{t}$ and $N_{t}$ are saving rate and labor amount respectively.

\subsection{Evaluating the Possibility of Takeoff in the Economy}

\subsubsection{Early Stage of Economic Development}

Before the government starts investing in infrastructure, we consider the period as an early stage of economic development where the economy remains in the absolute poverty trap. 
Alternatively, we also can refer it to the Traditional Society. ${ }^{7}$ Traditional Societies have the primordial pattern of trade, agricultural output and productivity and the trivial scale of manufacturing industries and households' real income. Consequently, the mainstream of the economy operates under the traditional technology. Because of the low wage rate in the labor market and high-interest rate in the domestic capital market, the economy primarily depends on the traditional technology.

As we consider no government investment in infrastructure capital in this stage, there is just a survival level of wage income. It means individuals live with a very low level of the wage rate, and a part of it is allocated for the next period's consumption as a saving. Hence, the capital per labor unit in this stage is flattened under extreme poverty and it is lower than the threshold level. Hence, the following condition can define this stage historically,

$$
S_{-1}=k_{0} \leq \underline{\mathrm{k}} .
$$

\subsubsection{Public Infrastructure Effect on the Threshold, and Takeoff}

When the government starts infrastructure investment, we denote this as Stage II (or the takeoff stage). Our concern in this sub-section is to determine whether public infrastructure capital helps the economic takeoff by increasing the productivity of modern technology and decreasing the threshold level and also to evaluate the possibility of success and failure in the takeoff process. We assume only modern technology can surpass the threshold level.

The threshold capital per labor unit in (18) is rewritten as

$$
\underline{\mathrm{k}}=\left[\frac{A_{\mathrm{T}}(G)}{(1-\alpha) A_{\mathrm{M}}(G)}\right]^{1 / \alpha} \equiv \underline{\mathrm{k}}(G) .
$$

Differentiating (21) to ascertain necessary inequalities:

$$
\frac{\partial \underline{\mathrm{k}}(G)}{\partial G}=A_{\mathrm{T}}^{\prime}(G) A_{\mathrm{M}}(G)-A_{\mathrm{T}}(G) A_{\mathrm{M}}^{\prime}(G) .
$$

According to (22), $\partial \underline{\mathrm{k}}(G) / \partial G<0$ and $\partial \underline{\mathrm{k}}(G) / \partial G \geq 0$ respectively correspond with,

$$
\begin{aligned}
& \frac{A_{\mathrm{T}}(G)}{A_{\mathrm{T}}(G)}<\frac{A^{\prime}{ }_{\mathrm{M}}(G)}{A_{\mathrm{M}}(G)}, \\
& \frac{A^{\prime}(G)}{A_{\mathrm{T}}(G)} \geq \frac{A^{\prime}{ }_{\mathrm{M}}(G)}{A_{\mathrm{M}}(G)} .
\end{aligned}
$$

As we consider the benevolent government, the public goods are free of the user fee, non-rivalry and non-excludable, where both types of firms (using traditional and modern technologies) can use it. However, the takeoff possibility depends on the productivity race between traditional and modern technology. Equation (23) states the elasticity of public capital on modern technology is larger than the elasticity of public capital on traditional technology. In other words, an increasing G has a relatively larger effect on the productivity

\footnotetext{
7 The early-stage economies are primarily based on traditional agriculture. Rostow (1959) defines this condition as a 'Traditional Society' which represents the first stage of the economy.
} 
of the modern sector than the productivity of the traditional sector. This inequality $\left(A^{\prime}{ }_{\mathrm{M}}(G) /\right.$ $\left.A_{\mathrm{M}}(G)>A^{\prime}{ }_{\mathrm{T}}(G) / A_{\mathrm{T}}(G)\right)$ sufficiently drops down the threshold level and the economy gets success in the takeoff process. Hence, this condition satisfies $\partial \underline{\mathrm{k}}(G) / \partial G<0 .^{8}$

PROPOSITION 1, (The effect of public capital on threshold and takeoff). If (23) holds, an increase in public capital helps the takeoff by reducing threshold:

$$
\frac{\partial \underline{k}(G)}{\partial G}<0 .
$$

\subsubsection{Tax Effect on Takeoff of the Economy}

This sub-section examines the effectiveness of tax on the takeoff. The savings in Stage II are represented as

$$
s_{I I}=k_{I I}=(1-\beta)\left(w_{t}-\tau\right) .
$$

Two conditions are possible in (26): first, $k_{I I}=(1-\beta)\left(w_{t}-\tau\right)>\underline{k}$ is the condition for takeoff success and second, $k_{I I}=(1-\beta)\left(w_{t}-\tau\right) \leq \underline{k}$ is the takeoff failure condition.

We can define (26) in the following form,

$$
F(\tau) \equiv(1-\beta)\left(A_{\mathrm{T}}(\tau N)-\tau\right)-\underline{k}(\tau N),
$$

where $F(0)<0$.

Differentiating (27) with respect to $\tau$ to obtain necessary inequality, which is written as

$$
\frac{\partial F(\tau)}{\partial \tau}=(1-\beta)\left(\frac{\partial A_{\mathrm{T}}(\tau N)}{\partial \tau}-1\right)-\frac{\partial \underline{k}(\tau N)}{\partial \tau} .
$$

In (28), $\partial F(\tau) / \partial \tau>0$ denotes takeoff success condition and $\partial F(\tau) / \partial \tau \leq 0$ denotes takeoff failure condition, and which are respectively corresponds with,

$$
\begin{aligned}
& \left(\frac{\partial A_{\mathrm{T}}(\tau N)}{\partial \tau}-1\right)>\frac{\partial \underline{k}(\tau N)}{\partial \tau} \\
& \left(\frac{\partial A_{\mathrm{T}}(\tau N)}{\partial \tau}-1\right) \leq \frac{\partial \underline{k}(\tau N)}{\partial \tau} .
\end{aligned}
$$

According to (29), if an increase in tax rate causes an increase in the output with traditional technology is larger than an increase in threshold level, this condition ensures takeoff success. In general, it defines a larger public capital flow in the economy as effective tax rate confirms an increase in wage rate (since $A_{\mathrm{T}}(\tau N)=w_{t}$ ). Hence, a higher wage rate implies a larger saving and eventually a larger capital accumulation. This condition satisfies $\partial F(\tau) / \partial \tau>0$.

\footnotetext{
${ }^{8}$ Conversely, $A^{\prime}{ }_{\mathrm{T}}(G) / A_{\mathrm{T}}(G) \geq A^{\prime}{ }_{\mathrm{M}}(G) / A_{\mathrm{M}}(G)$ states the elasticity of public capital on traditional technology is relatively larger than the elasticity of public capital on modern technology. More clearly, if the increasing public capital enhances the productivity of the traditional sector relatively higher than the modern sector, the threshold level also increases. Thus, it disrupts the takeoff process because of the lower capital per labor failures in surpassing the threshold. This condition satisfies $\partial \underline{\mathrm{k}}(G) / \partial G \geq 0$.
} 
In addition, let's assume that a change in tax rate has a negative effect. Also in this condition, there may still be a possibility of takeoff. When the rate of decline in the left-hand side of (29) is lower than a rate of decline in the right-hand side, this condition also ensures $\partial F(\tau) / \partial \tau>$ 0 . More convincingly, if the declining rate in threshold is sufficiently larger than the declining rate in saving because of the change in tax rate, it still ensures a takeoff success in the economy. ${ }^{9}$

Moreover, let $F(\hat{\tau})=0$ be the critical level for determining effective tax rate for public infrastructure financing below which it can't be possible to finance. Thus, when $\tau>\hat{\tau}$, it can be possible to obtain (29). Hence, proposition (2) can be satisfied.

PROPOSITION 2, (The effect of the tax on the takeoff). The following two conditions correspond to (29) ensure an increase in tax rate helps the takeoff through public infrastructures:

$$
\partial F(\tau) / \partial \tau>0, \quad F(\tau)>0
$$

\subsection{Capital Accumulation in the Economy}

The following ordinary assumption holds when the economy succeeds in the takeoff process,

$$
\underline{k}<k_{0}=s_{-1} .
$$

As per the assumption, only modern technology can get success in the takeoff process. We assume this stage is the third stage (III) of economic development. In this stage, the modern sector gets largely benefitted from increasing government infrastructure capital. By assuming (32), the economy starts to rise in wage rate and resulting rise in $s_{t}$ and $k_{t+1}$. Hence, this cycle increases an individual's income and, the economy gradually escapes out from poverty.

Rewriting (4),

$$
s_{t}=(1-\beta)\left(w_{t}-\tau\right)
$$

When saving increases sufficiently, it ensures the firm's capital accumulation sufficiently along with increasing public capital. By assuring the dynamic path in the model, saving determines capital per labor unit of the next period. This condition means $\Delta k_{t}>0$. When capital per labor gets success in the takeoff process, then by experiencing rapid growth in the dynamics, the economy gradually converts into the steady-state level. Hence, the following equation ensures the capital per labor dynamics,

$$
k_{t+1}=(1-\beta)\left[(1-\alpha) A_{\mathrm{M}}(G) k_{t}^{\alpha}-\tau\right],
$$

where $k_{t+1}$ is capital per labor accumulation in period $t+1$. The (34) has properties similar to the central equation in the Solow model. Let's check the slope,

\footnotetext{
${ }^{9}$ In contrast, if (30) holds, it interrupts the takeoff process and the economy remains in a poverty trap. In detail, if an increase in tax rate causes an increase in the output with traditional technology is lower than an increase in threshold level, this condition disrupts the takeoff process. It means a weak public capital flow through inefficient tax rates in the economy. Moreover, it also defines a decrease in wage rate, and hence, a negative impact on saving and capital accumulation. This condition satisfies $\partial F(\tau) / \partial \tau \leq 0$.
} 


$$
\frac{d k_{t+1}}{d k_{t}} \equiv \alpha(1-\beta)(1-\alpha) A_{\mathrm{M}}(G) k_{t}^{\alpha-1}
$$

In (35), the slope is positive. The magnitude of the slope depends on the value of $k_{t}$. Hence, as $f^{\prime}\left(k_{t}\right)$ is positive, the slope is positive. Figure (2) depicts that the economy initially remains in a poverty trap with lower capital per labor, $k_{0}$, which is less than the threshold value $\underline{k}$. However, when $k_{0}>\underline{k}$, economy succeeds in the takeoff process and capital dynamics start simultaneously. After takeoff success, $k_{t+1}$ initially starts with a very steeper slope and increase with a decreasing rate and gradually orients to zero, and finally crosses the 45-degree line. This interaction exists a steady state in which $k_{t+1}=k_{t}=k^{*}$

By using (34), we define the following implicit function in the steady-state:

$$
H\left(k^{*} ; \beta, \alpha, G, \tau\right) \equiv k^{*}-(1-\beta)\left[(1-\alpha) A_{\mathrm{M}}(G) k_{t}^{\alpha}-\tau\right] .
$$

Let's differentiate implicit function to identify the effect of tax and public infrastructure on steady-state,

$$
\frac{\partial k^{*}}{\partial z}=-\frac{\partial H\left(k^{*} ; .\right) / \partial z}{\partial H\left(k^{*} ; .\right) / \partial k^{*}}
$$

where $z=\beta, \alpha, G, \tau$. Under figure (2) the following equation can be written,

$$
\frac{\partial H\left(k^{*} ; .\right)}{\partial k^{*}}=1-(1-\beta) \frac{\partial\left[(1-\alpha) A_{\mathrm{M}}(G) k^{* \alpha}-\tau\right]}{\partial k^{*}}>0 .
$$

In steady-state, an increase in lump-sum tax rate cannot increase steady-state capital per labor unit because it has a negative effect, $\frac{\partial k^{*}}{\partial \tau}<0$. However, an increase in public investment in infrastructure capital can increase steady-state capital per labor unit. This condition can be written as, $\frac{\partial k^{*}}{\partial G}>0$.

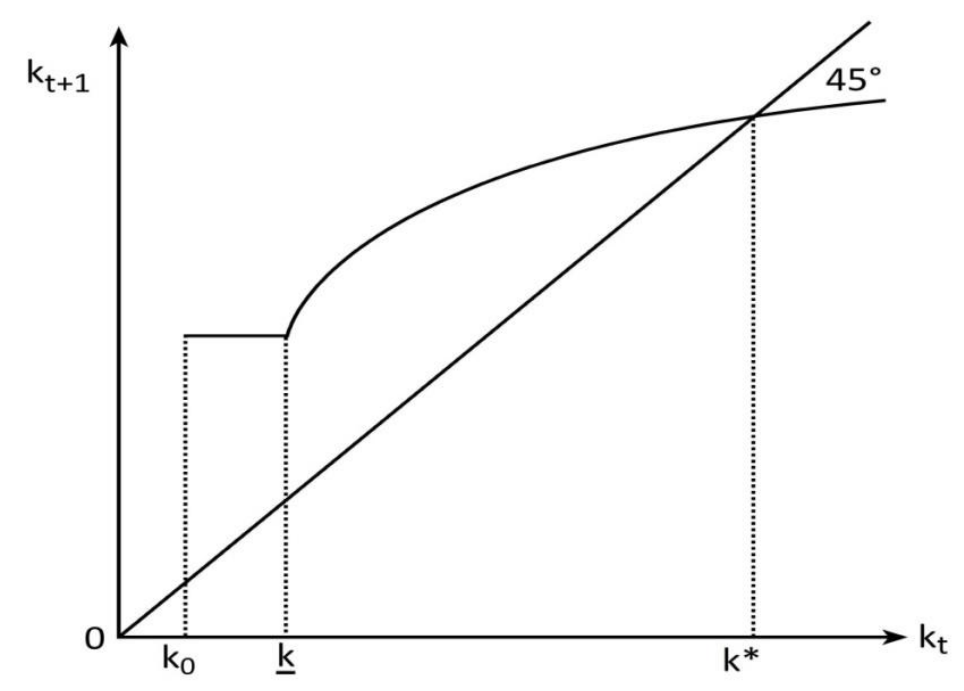

Figure 2. Capital dynamics 
Since there is only modern technology in the economy, capital becomes abundant and wage becomes scared. Similarly, interest rate decreases sufficiently; however, the wage rate increases. In general, a rise in $k_{t+1}$ implies a downfall in the interest rate and there might be a possibility of a decrease in saving rate. However, as per our two-period OLG model, the saving of young individuals is a non-decreasing function of the interest rate. At the same time, the government also works as a social planner; stimulate saving and increases public capital sufficiently through its expansionary fiscal policy. Thus, increasing public capital plays a significant role in poverty alleviation and income growth.

\section{Review of Related Empirical Literatures}

This section summarizes the empirical evidences that are related to the role of public capital on economic development. There are numerous literatures in this area; however, we specifically concentrate on the role of physical infrastructures such as road, electricity, telephone and internet, water and sanitation, etc. on takeoff of the economy. Simultaneously, we try to summarize the literatures on the wider dimension of public capital. Table 2 presents a summary of major studies that are taken into consideration in this section.

The majority of the studies in this area claim that improvement in infrastructure fosters productivity and lowers the costs associated with firms; however, a few literatures disagree with the findings of majorities. The US-based empirical studies in the eighties and nineties [see Aschauer (1989a, 1989b, 1989c), Eberts (1986), Holtz-Eakin (1992), Holtz-Eakin and Schwartz (1994), Munnell (1990a, 1990b, 1992) and more] have significant contribution in this area. In particular, a seminal work of Aschauer (1989a) investigates the nexus between aggregate productivity and government spending by using US data from 1949 to 1985 . He finds the coefficient of 0.39 for aggregate nonmilitary capital (where the coefficient for core infrastructure capital is 0.24, which is highly significant). Similarly, Eberts (1986), who evaluates the effect of public capital stock on regional manufacturing sectors of 38 metropolitan areas of the US from 1958 to 1981 by using a perpetual inventory method, finds the positive and significant effect of public capital on manufacturing output. However, the effect is less than that of private capital and labor, where public capital stock includes roads, highways, and water treatment and supply. ${ }^{10}$ In contrast, by using OLS techniques for the data of 48 states of the US from 1969 to 1986, Holtz-Eakin (1992) finds that there is no effect of public capital on the private sector having an elasticity of 0.20 . Moreover, he doesn't find any important impact of the road network, bridges, water supply system, sewage facilities, and other infrastructure services. In addition, Holtz-Eakin and Schwartz (1994) also find the same result with an output elasticity of 0.10 , which implies the negligible impact of growing infrastructure on productivity growth.

Besides the earlier US-based studies, the majority of investigations also have similar arguments. Canning (1999) conducts research by executing the co-integration methods in stationary nature cross country data from 1960 to 1990 and identifies the very significant impact of the telephone on aggregate output, whereas electricity, paved roads, and railways

\footnotetext{
${ }^{10}$ Many studies determine the positive effect of public capital on private output including Munnell (1990a, 1990b, 1992).
} 
don't have satisfactory effects on the output. Similarly, Ferrara et al. (2000) uses Italian data from 1970 to 1994 and finds productive results of infrastructures such as railways, roads, and airports on TFP growth. Additionally, a survey of India's Golden Quadrilateral Program by Datta (2012) concludes the positive impact of highway infrastructure on the productivity of firms. Likewise from Chinese rural sector study by Fan and Zhang (2004) find a positive impact of rural physical infrastructure investment on increasing agricultural productivity, rural nonfarm employment and urbanization.

There are some differences among the studies in regard to increasing public investment whether crowds-out or crowds-in private investment. Munnell (1992) contends that public infrastructure investment crucially stimulates private investment because, on the one hand, it fosters overall investment and private productivity but, on the other hand, from investors' perspective, it crowds-out private capital. ${ }^{11}$ In a similar study, Eden and Kraay (2014) conduct a study of 39 low-income countries using CES production function to evaluate the crowding-in effect and identify a crowd-in private investment effect of increasing public capital, where one dollar of government capital fosters additional 2 dollars of private investment and 1.5 dollars of output. Moreover, the paper claims a strong complementary relationship between government capital and private capital. However, in the context of developing economies, Cavallo and Daude (2011) use time-series and cross-sectional variation in the data to explore the empirical correlations between public and private investment, and suggests negative effects, where public capital crowds-out private investment. In this respect, Eberts (1986) advocates both substitutable and complementary relationship, where he claims the substitutable relationship between public and private capital and private capital and labor input, and complementary relationship between public capital and labor inputs.

In regards to long-run growth, poverty alleviation and income inequality, there are contradictory findings; however, the majority of literatures argue on the positive effect of public capital on every respect. An empirical study of G7 countries by Aschauer (1989c) concludes that public capital is a vital ingredient for economic growth. By using panel data of more than 100 countries from 1960 to 2000 based on the GMM estimation technique, Calderon and Serven (2004) get the positive impact of increasing the quality and quantity of infrastructure on growth and income inequality declining. ${ }^{12}$ Leduc and Wilson (2013)

\footnotetext{
11 Aschauer (1989b) has also a similar argument; an increase in public investment impacts a nominal dropdown in accumulating private investment, however, aggregate national-level investment ratio increases significantly, and the profitability of private capital also increases correspondingly. Additionally, Munnell (1990b) also discovers the positive result of public capital on private investment and employment.

12 However, in another study, they find a dissimilar result in terms of income inequality by observing more than 100 countries from 1960 to 2005 . An increase in infrastructure quantity and quality has a positive effect on long-run growth but the negative impact on income inequality. They define synthetic quantity index in the basic equation as $I K=0.603^{*} \ln \left(Z_{1} / L\right)+0.613^{*} \ln \left(Z_{2} / L\right)+0.510^{*} \ln \left(Z_{3} / A\right)$. Where, $Z_{1} / L$ define total telephone line per 1000 workers, $Z_{2} / L$ defines electric power generating capacity in MW per 1000 workers, and $Z_{3} / A$ defines the length of road in $\mathrm{km}$ per square $\mathrm{km}$ of arable land. Similarly, for a basic synthetic quality index, they define $I Q=0.608^{*} Q_{1}+0.559^{*} Q_{2}+0.564^{*} Q_{3}$, where $Q_{1}, Q_{2}$ and $Q_{3}$ are waiting time (in years) for the installation of main telephone lines, the percentage of transmission and distribution losses in the production of electricity, and the share of paved roads in total roads respectively. By using an alternative index of infrastructure they also check robustness in the result [see Calderon and Serven (2008)].
} 
considers the effects of exogenous shocks on federal highway spending across US states and finds only short-run effects on GDP. Many regional studies focus on the East Asian economies have also shown a significant effect of public infrastructure capital on growth and poverty reduction [see Kim (2006), Kim and Lee (2010), World Bank (1993, 1994)]. A study of five ASEAN countries (Indonesia, Philippines, Malaysia, Thailand, and Vietnam) by Seneviratne and Sun (2013) explores that better infrastructure can enhance inclusive growth and poverty reduction; however, there isn't any indication of a reduction in income inequality. A study based on Turkey from 1965 to 2000 by using the co-integration and Granger Causality test, Bagdigen and Cetintas (2004) find no long-run relationship between public expenditures and GDP.

Many empirical studies focusing on the Sub-Saharan African Region have similar conclusions that poor infrastructures are the root cause of lower growth and poverty trap in the region [see Calderon and Serven (2008), Collier and Venables (2016), Kodongo and Ojah (2016) and more]. As a radical issue of domestic policy of poor countries, Collier and Venables (2016) conduct research of African cities, infrastructures, and connectivity, and suggest fundamental improvement in infrastructure and connectivity in urban and national level for productivity growth. Moreover, Kodongo and Ojah (2016) suggest that infrastructure capital in poor countries has a relatively larger impact than in relatively developed countries in the region. In a sample of 14 EU countries from 1990 to 2006, Benos (2009) concludes a growth-enhancing effect of infrastructure spending. In addition, Cockburn et al. (2013), in their book 'Infrastructure and Economic Growth in Asia', conclude the positive role of public infrastructure spending on economic growth and poverty alleviation. A regional study by Calderon and Serven (2010) conclude a positive impact of increasing infrastructure stock and quality on enhancing long-run growth and poverty reduction in Latin America.

Differently, there are some empirical studies that are centrally focused on evaluating the take-off in the early stage of development. Fundamentally, initial takeoff is very important for low-income economies. Once the economy is able to succeed in the takeoff process, there is a high possibility of persistent growth on the aggregate output, and the impact of infrastructure capital is more significant in those economies than in high-income economies. However, some of the empirical investigations in this respect only focus on the takeoff and landing time, and takeoff sustainability by determining various benchmark indications [see Aizenman and Spiegel (2010), Pakrashi and Frijters (2017), Easterly (2006) and more]. In these studies, the role of public infrastructure capital has not been investigated primarily as a major driving force of takeoff. Nevertheless, the empirical facts stated in this section illustrate the vital role of public infrastructure on poverty alleviation, takeoff, and the aggregate growth in the economy. 
Table 2. Summary of major empirical literatures

\begin{tabular}{|c|c|c|}
\hline Literature & Sampling & Major findings \\
\hline Aschauer (1989) & $\begin{array}{l}\text { US yearly } \\
1949 \text { to } 1985\end{array}$ & $\begin{array}{l}\text { Infrastructure has most explanatory power for productivity (coefficient } \\
\text { of } 0.39 \text { for aggregate non-military capital, were } 0.24 \text { for core } \\
\text { infrastructures) }\end{array}$ \\
\hline Aschauer (1989c) & G-7 countries, 1966-1985 & $\begin{array}{l}\text { A strong, positive correlation between public capital expenditure and } \\
\text { various productivity measures }\end{array}$ \\
\hline Canning (1999) & 57 countries, $1960-1990$ & $\begin{array}{l}\text { Highly significant effects of the telephone on aggregate output, } \\
\text { however, electricity and paved roads and railways have no } \\
\text { satisfactory effects }\end{array}$ \\
\hline Holtz-Eakin (1992) & US-state data, 1969-1986 & Negligible impact of increasing infrastructures on productivity growth \\
\hline $\begin{array}{l}\text { Munnell (1990a, } \\
\text { 1990b, 1992) }\end{array}$ & US database & $\begin{array}{l}\text { The positive impact of public capital on labor productivity, private } \\
\text { output efficiency, and private investment and employment }\end{array}$ \\
\hline Ferrara et al. (2000) & Italian data, 1970-1994 & $\begin{array}{l}\text { Productive effect of infrastructure on TFP growth, output, and cost } \\
\text { reduction. }\end{array}$ \\
\hline Datta (2012) & Indian firm's survey & Productive effect of highway on the firm's productivity \\
\hline $\begin{array}{l}\text { Eden and Kraay } \\
(2014)\end{array}$ & $\begin{array}{ll}39 & \text { low-income } \\
\text { economies } & \end{array}$ & $\begin{array}{l}\text { One extra dollar of government investment raises private investment } \\
\text { by roughly } 2 \text { dollars and output by } 1.5 \text { dollars }\end{array}$ \\
\hline $\begin{array}{l}\text { Cavallo and Daude } \\
\text { (2011) }\end{array}$ & 116 developing countries & In general public investment crowd-out private investment \\
\hline $\begin{array}{l}\text { Calderón and Servén } \\
\text { (2004) }\end{array}$ & $\begin{array}{l}\text { Over } 100 \text { countries, } \\
1960-2000\end{array}$ & $\begin{array}{l}\text { Infrastructure capital has a positive robust effect on growth and } \\
\text { income inequality }\end{array}$ \\
\hline $\begin{array}{l}\text { Leduc and Wilson } \\
\text { (2013) }\end{array}$ & US-state data, 1990-2010 & Highway spending has only short-run positive effects on GDP \\
\hline $\begin{array}{l}\text { Kim (2006), Lee } \\
(2010)\end{array}$ & Japan and Korean data & $\begin{array}{l}\text { A significant role of infrastructure investment in rapid economic } \\
\text { development }\end{array}$ \\
\hline $\begin{array}{l}\text { Seneviratne and Sun } \\
\text { (2013) }\end{array}$ & $\begin{array}{l}\text { ASEAN-5 countries, } \\
1980-2010\end{array}$ & Infrastructure development promotes income equality and growth. \\
\hline $\begin{array}{l}\text { Calderón and Servén } \\
\text { (2008) }\end{array}$ & $\begin{array}{l}100+\quad \text { countries, } \\
1960-2005, \quad \text { focusing } \\
\text { Sub-Saharan Africa }\end{array}$ & $\begin{array}{l}\text { Infrastructure quantity and quality has a positive effect on long-run } \\
\text { growth but a negative effect on income inequality. Sufficient } \\
\text { infrastructure can have a larger effect in reducing poverty in } \\
\text { Sub-Saharan Africa }\end{array}$ \\
\hline $\begin{array}{l}\text { Calderón and Servén } \\
\text { (2010) }\end{array}$ & $\begin{array}{l}\text { Latin } \\
1960-2005\end{array}$ & $\begin{array}{l}\text { Infrastructure quantity and quality has a positive effect on long-run } \\
\text { growth }\end{array}$ \\
\hline $\begin{array}{l}\text { Kodongo and Ojah } \\
\text { (2016) }\end{array}$ & $\begin{array}{l}45 \text { Sub-saharan African } \\
\text { countries, 2000-2011 }\end{array}$ & $\begin{array}{l}\text { Infrastructure spending has a positive impact on growth and } \\
\text { development, and poorer countries have a relatively larger impact }\end{array}$ \\
\hline $\begin{array}{ll}\text { Bagdigen } & \text { and } \\
\text { Cetintas (2003) }\end{array}$ & Turkey, 1965-2000 & No long-run relationship between public expenditure and growth \\
\hline $\begin{array}{l}\text { Collier and Venables } \\
(2003)\end{array}$ & African Cities & Infrastructure is essential for urbanization and growth \\
\hline Benos (2009) & $\begin{array}{l}14 \quad \mathrm{EU} \\
1990-2006\end{array}$ & Public infrastructure spending enhances growth \\
\hline
\end{tabular}




\section{Conclusions}

This paper has considered the effect of public infrastructure investment on the economic development process in early-stage economies. Taking this into account, we have used a two-period overlapping generations model, and also considered two types of technologies (traditional and modern) which are used to produce the final output of firms. This paper concludes that economic takeoff is possible only when the capital per labor unit exceeds a certain threshold. Thus, the takeoff process depends on the productivity race between the traditional and modern sectors with increasing public infrastructure investment, while public infrastructure fosters the productivity of both technologies. Similarly, an effective tax rate is essential to get success in the takeoff process by stimulating the wage rate which in turn increases the capital per labor along with the saving rates. Additionally, when the economy succeeds in the takeoff process, increasing public capital raises individuals' income and, the economy can get out of the vicious circle of poverty. This paper also confirms that when the economy converges to the steady-state level, a further increase in tax rate has negative effect on capital per labor unit. However, a further increase in public infrastructure capital has positive effect on steady-state capital per labor unit. Furthermore, by reviewing empirical literatures, we found public infrastructure has a vibrant role in the development process.

\section{Acknowledgments}

I would like to thank Professor Hideki Nakamura for his efforts in the supervision of this paper.

\section{References}

Agenor, P. R. (2006). A Theory of Infrastructure-led Development. Discussion paper series, CGBCR, Economic Studies. University of Manchester, M13 9PL, UK. [Online] Available: http://hummedia.manchester.ac.uk/schools/soss/cgbcr/discussionpapers/dpcgbcr135.pdf

Agenor, P. R. (2008). Health and Infrastructure in a Model of Endogenous Growth. Journal of Macroeconomics, 30, 1407-1422. https://doi.org/10.1016/j.jmacro.2008.04.003

Agenor, P. R., \& Neanidis, R. C. (2011). The Allocation of Public Expenditure and Economic Growth. The Manchester School, 79(4), 899-931.

https://doi.org/10.1111/j.1467-9957.2011.02197.x

Aizenman, J., \& Spiegel, M. M. (2010). Takeoffs. Review of Development Economics, 14(2), 177-196. https://doi.org/10.1111/j.1467-9361.2010.00546.x

Arrow, K., \& Kurz, M. (1970). Public Investment, the Rate of Return, and Optimal Fiscal Policy. Baltimore: Johns Hopkins University Press. [Online] Available:

https://www.taylorfrancis.com/books/9781315064178

Aschauer, D. A. (1989a). Is Public Expenditure Productive?. Journal of Monetary Economics, 23, 177-200. https://doi.org/10.1016/0304-3932(89)90047-0

Aschauer, D. A. (1989b). Does Public Capital Crowd Out Private Capital?. Journal of Monetary Economics, 24(2), 171-188. https://doi.org/10.1016/0304-3932(89)90002-0 
Aschauer, D. A. (1989c). Public Investment and Productivity Growth in the Group of Seven. Federal Reserve Bank of Chicago, Economic Perspectives, 13(5), 17-25. [Online] Available: https://ideas.repec.org/a/fip/fedhep/y1989isepp17-25nv.13no.5.html

Bagdigen, M., \& Cetintas, H. (2004). Causality between Public Expenditure and Economic Growth: The Turkish Case. Journal of Economic and Social Research, 6(1), 53-72. [Online] Available: https://mpra.ub.uni-muenchen.de/8576/

Barro, R. J. (1990). Government Spending in a Simple Model of Exogenous Growth. Journal of Political Economy, 98, 103-125. https://doi.org/10.1086/261726

Benos, N. (2009). Fiscal Policy and Economic Growth: Empirical Evidence from EU Countries. The University of Loannina, MPRA paper 19174. [Online] Available:

https://mpra.ub.uni-muenchen.de/19174/1/MPRA_paper_19174.pdf

Bucci, A., \& Del Bo, C. (2011). On the Interaction between Public and Private Capital in Economic Growth. Journal of Economics, 106(2), 133-152.

https://doi.org/10.1007/s00712-011-0239-3

Calderon, C., \& Serven, L. (2004). The Effects of Infrastructure Development on Growth and Income Distribution. World Bank Policy Research Working Paper No. 3400.

https://doi.org/10.1596/1813-9450-3400

Calderon, C., \& Serven, L. (2008). Infrastructure and Economic Development in Sub-Saharan Africa. World Bank Policy Research Working Paper 4712.

https://doi.org/10.1596/1813-9450-4712

Calderon, C., \& Serven, L. (2010). Infrastructure in Latin America. World Bank Policy Research Working Paper 5317. https://doi.org/10.1596/1813-9450-5317

Canning, D. (1999). Infrastructure's Contribution to Aggregate Output. Policy Research Working Paper Series 2246, The World Bank. https://doi.org/10.1596/1813-9450-2246

Cavallo, E., \& Daude, C. (2011). Public Investment in Developing Countries: A Blessing or A Curse?. Journal of Comparative Economics, 39, 65-81.

https://doi.org/10.1016/j.jce.2010.10.001

Cazzavillan, G. (1996). Public Spending, Endogenous Growth, and Endogenous Fluctuations. Journal of Economic Theory, 71(2), 394-415. https://doi.org/10.1006/jeth.1996.0127

Chatterjee, S., \& Turnovsky, S. J. (2012). Infrastructure and Inequality. European Economic Review, 56, 1730-1745. https://doi.org/10.1016/j.euroecorev.2012.08.003

Chen, B. L. (2006). Economic Growth with an Optimal Public Spending Consumption. Oxford Economic Papers, 58, 123-136. https://doi.org/10.1093/oep/gpi045

Cockburn, J., Dissou, Y., Duclos, J. Y., \& Tiberti, L. (2013). Infrastructure and Economic Growth in Asia. Springer Cham Heidelberg New York Dordrecht London: Springer Open and Partnership for Economic Policy. https://doi.org/10.1007/978-3-319-03137-8 


\section{Al Macrothink}

Business and Economic Research ISSN 2162-4860 2020, Vol. 10, No. 1

Collier, P., \& Venables, A. J. (2016). Urban Infrastructure for development. Oxford Review of Economic Policy, 32(3), 391-409. https://doi.org/10.1093/oxrep/grw016

Datta, S. (2012). The Impact of Improved Highways on Indian Firms. Journal of Development Economics, 99, 46-57. https://doi.org/10.1016/j.jdeveco.2011.08.005

Easterly, W. (2006). Reliving the 50s: The Big Push, Poverty Traps, and Takeoffs in Economic Development. Journal of Economic Growth, 11, 289-318.

https://doi.org/10.1007/s10887-006-9006-7

Eberts, R. W. (1986). Estimating the Contribution of Urban Public Infrastructure to Regional Growth. Working Paper 86-10, Federal Reserve Bank of Cleveland.

https://doi.org/10.26509/frbc-wp-198610

Eden, M., \& Kraay, A. (2014). "Crowding In" and the Returns to Government Investment in Low-income Countries. Policy Research Working Paper Series 6781, The World Bank. https://doi.org/10.1596/1813-9450-6781

Fan, S., \& Zhang, X. (2004). Infrastructure and Regional Economic Development in Rural China. China Economic Review, 15, 203-21. https://doi.org/10.1016/j.chieco.2004.03.001

Ferrara, E. L., Marcellino, M. G., \& Bonaglia, F. (2000). Public Capital and Economic Performance: Evidence from Italy. IGIER Working Paper No. 163.

https://doi.org/10.2139/ssrn.230469

Galor, O., \& Moav, O. (2004). From Physical to Human Capital Accumulation: Inequality and the Process of Development. Review of Economic Studies, 71, 1001-1026.

https://doi.org/10.1111/0034-6527.00312

Getachew, Y. Y. (2010). Public Capital and Distributional Dynamics in a Two-sector Growth Model. Journal of macroeconomics, 32, 606-616.

https://doi.org/10.1016/j.jmacro.2009.12.009

Glomm, G., \& Ravikumar, B. (1997). Productive Government Expenditures and Long-run Growth. Journal of Economic Dynamics and Control, 21, 183-204.

https://doi.org/10.1016/0165-1889(95)00929-9

Hashimazde, N., \& Myles, R. D. (2010). Growth and Public Infrastructure. Macroeconomic Dynamics, 1-17, Cambridge University Press 1365-1005/10.

https://doi.org/10.1017/S1365100510000374

Holtz-Eakin, D. (1992). Public-Sector Capital and the Productivity Puzzle. NBER Working Paper No.4122. https://doi.org/10.3386/w4122

Holtz-Eakin, D., \& Schwartz, A. E. (1994). Infrastructure in a Structural Model of Economic Growth. NBER Working Paper 4824, 1050 Massachusetts Avenue, Cambridge, MA 02138. https://doi.org/10.3386/w4824

KIM, J. K., \& Lee, C. H. (2010). Finance and Economic Development in Korea. SIRFE Working Paper 10-A05. [Online] Available: 
http://eng.sirfe.com/index.php?mid=WorkingPaper\&page=3

KIM, B. (2006). Infrastructure Development for Economic Development in Developing Countries: Lessons from Korea and Japan. GSICS Working Paper Series 11, GSICS, Kobe University. [Online] Available:

http://www.research.kobe-u.ac.jp/gsics-publication/gwps/2006-11.pdf

Kodongo, O., \& Ojah, K. (2016). Does Infrastructure Really Explain Economic Growth in Sub-Saharan Africa?. Review of Development Finance, 6, 105-125.

https://doi.org/10.1016/j.rdf.2016.12.001

Leduc, S., \& Wilson, D. (2013). Roads to Prosperity or Bridges to Nowhere? Theory and Evidence on the Impact of Public Infrastructure Investment. NBER Macroeconomics Annual, 27(1), 89-142. https://doi.org/10.1086/669173

Munnell, A. H. (1990a). Why Has Productivity Growth Declined? Productivity and Public Investment. New England Economic Review, pp. 3-22, [Online] Available:

https://ideas.repec.org/a/fip/fedbne/y1990ijanp3-22.html

Munnell, A. H. (1990b). How Does Public Infrastructure Affect Regional Economic Performance? New England Economic Review, pp. 11-32, [Online] Available:

https://ideas.repec.org/a/fip/fedbne/y1990isepp11-33.html

Munnell, A. H. (1992). Policy Watch: Infrastructure Investment and Economic Growth. The Journal of Economic Perspectives, 6(4), 189-198. https://doi.org/10.1257/jep.6.4.189

Nakamura, H., \& Mihara, Y. (2016). Effect of Public Health Investment on Economic Development Via Savings and Fertility. Macroeconomic Dynamics, 20, 1341-1358.

https://doi.org/10.1017/S1365100514000911

Ott, I., \& Turnovsky, S. (2006). Excludable and Non-excludable Public Inputs: Consequences for Economic Growth. Economica, 73, 725-748.

https://doi.org/10.1111/j.1468-0335.2006.00506.x

OXFORD ECONOMICS, Global Infrastructure Hub. (2017). Global Infrastructure Outlook. [Online] Available: https://outlook.gihub.org/

Pakrashi, D., \& Frijters, P. (2017). Takeoffs, Landing, and Economic Growth. ADBI Working Paper No. 641. https://doi.org/10.2139/ssrn.2955480

Rosenstein-Rodan, P. N. (1943). Problems of Industrialization of Eastern and South-Eastern Europe. Economic Journal, 53, 202-211. https://doi.org/10.2307/2226317

Rostow, W. W. (1959). The Stages of Economic Growth. The Economic History Review, New Series, 12(1), 1-16. https://doi.org/10.1111/j.1468-0289.1959.tb01829.x

Sachs, J. D. (2005). The End of Poverty: Economic Possibilities for Our Time. New York: The Penguin Press.

Seneviratne, D., \& Sun, Y. (2013). Infrastructure and Income Distribution in ASEAN-5: what 
are the links?. IMF Working Paper 13/41. https://doi.org/10.5089/9781589068018.001

World Bank (1993). The East Asian Miracle: Economic Growth and Public Policy. New York: Oxford University Press. [Online] Available:

http://documents.worldbank.org/curated/en/975081468244550798/pdf/multi-page.pdf

World Bank (1994). Infrastructure for Development. Published for World Bank, Oxford University. [Online] Available: http://hdl.handle.net/10986/5977

World Bank (2018). Poverty and Shared Prosperity 2018: Piecing Together the Poverty Puzzle. Washington DC: World Bank. License: Creative Commons Attribution CC BY 3.0 IGO. [Online] Available:

https://www.worldbank.org/en/publication/poverty-and-shared-prosperity

\section{Copyright Disclaimer}

Copyright for this article is retained by the author(s), with first publication rights granted to the journal.

This is an open-access article distributed under the terms and conditions of the Creative Commons Attribution license (http://creativecommons.org/licenses/by/4.0/). 